DÁNIEL DEÁK*

\title{
Conflicts between Hungarian Procedural Tax Law and Community Law-Case Studies"
}

\begin{abstract}
In this paper, the administrative law aspect of the compatibility of the Hungarian local trade tax will be discussed, based on the presumption that even if it has been declared that the Hungarian local trade tax cannot be considered inconsistent with the harmonised value added tax, Hungarian taxpayers may be hurt in their rights if they cannot get easy access to the clarification of the legal issue whether a national tax is consistent with Community law.
\end{abstract}

Keywords: enforcement of compatibility with harmonised value added tax of Hungarian local trade tax; state liablity of the damage caused by wrong legislation; taxpayer claims based solely on the infringement of Article $10 \mathrm{EC}$

In the following, procedural tax law issues will be raised through case studies. Their subject is the Hungarian local trade tax. It was tested before the ECJ whether the Hungarian tax was not in competition with the harmonised value added tax. A number of Hungarian taxpayers claimed that it was not. Although their claims were not approved by the ECJ, the question cannot be confined to the substantive law issue. This is because not only the question can be formulated if the Hungarian tax is consistent with Article 33 of the Sixth Council Directive (now Article 404 of Directive 2006/112/EC), but another question as well. The latter is of procedural law nature. The smooth operation of the harmonised value added tax can be jeopardised not only by introducing

* Full Professor of Law, Corvinus University of Budapest, Institute of Business Law; Research Fellow, Taxation Law and Policy Research Institute, Monash University, Melbourne E-mail: daniel.deak@uni-corvinus.hu

** This paper was written within the framework of the project $\mathrm{N}^{0}$ NKFPG-00075/2005 on "The effects of European Union's membership on Hungarian law and administration".

The present article is part of a major study. Deák, D.: Az EU-csatlakozás hatása a magyar adóigazgatási eljárási jogra: jogbiztonság, egyéni jogvédelem és ekvivalenciakövetelmény az adózásban (The impact of the EU accession on the Hungarian procedural law of tax administration: legal certainty, individual legal protection and the standard of equivalence in taxation). In: Lörincz, L. (ed.): Látleletek a magyar közigazgatásról (Findings on the Hungarian public administration). Budapest, 2007, 63-123. 
taxes in competition with the value added tax as introduced by the Sixth Council Directive. It can also be an impediment to the smooth operation of the harmonised value added tax that taxpayers cannot easily clarify whether a national tax as introduced is consistent or not with the harmonised value added tax. Taxpayers may be compelled-as the case is in Hungary-to undertake to file tax returns with zero tax liability, and envisage the adverse tax consequences of identifying the unpaid tax, if they wish to express their doubts as to the national tax as introduced, whether it is compatible with the harmonised value added tax. This is because they do not have the right in Hungary to file tax returns with the right of reservation. This can be seen, taken by itself, as a breach of the loyalty principle as enshrined in Article 10 of the EC Treaty.

In the following, the administrative law aspect of the compatibility of the Hungarian local trade tax will be discussed, based on the presumption that even if it has been declared that the Hungarian local trade tax cannot be considered inconsistent with the harmonised value added tax, Hungarian taxpayers may be hurt in their rights if they cannot get easy access to the clarification of the legal issue whether a national tax is consistent with Community law. First, the above question will be put in the context of a lawsuit of public administration, the subject of which is to examine whether the resolution of the local tax authorities on the imposition of the advance local trade tax is lawful. Secondly, the problem with the inconsistency of local trade tax with Community law will be extended to the possible delictual liability of the state for the damages caused by the introduction of tax not duly levied, that is, by the legislation not consistent with Community law. Again, even if the controversy on the compatibility of the local trade tax has been over, the question has remained open if the Republic of Hungary can be sued under certain conditions for compensating the damages caused by wrong legislation.

\section{Examining the legality of levying local business tax in the context of Community law}

\section{Background}

According to one viewpoint, a legal case can be brought against the bureau chief of the Public Administrative Office of the County of Zala as defendant, petitioning the Court to review a decision he signed in 2005, which let stand a warrant for payment issued by the Mayor's Office of the Municipality of Zalaegerszeg. The applicant may contend that he was correct to petition the Court to declare that decisions produced by the defendant were violating the 
law, because as of May 1, 2004, when the Republic of Hungary joined the European Union, Paragraph 129 (1) of Article 33 of the Sixth Council Directive $77 / 388 /$ EEC $^{1}$ became directly available to the applicant, and thus the applicant had no liability for the relevant tax. Consequently, it was not in accordance with the law to prescribe the applicant the obligation to make an advance payment connected to the 2005 tax year.

The applicant moved to initiate a preliminary ruling proceeding in front of the European Court of Justice, for-among other objectives-to get an interpretation of whether the local business tax (in Hungarian: "helyi iparüzési adó") can be upheld following accession, or whether it conflicted with Article 33 of the Sixth Council Directive. ${ }^{2}$ Another issue that was raised was whether 3(a) [on Local authority fiscal aid] of Part 4 [on Competition Policy] of Appendix $X$ of the EU Accession Treaty ${ }^{3}$ could be interpreted in such a way that the accession document granted a temporary waiver (i.e. one that is limited to a term of transition) to the Republic of Hungary, which would provide the option that Hungary may-if it so chooses-derogate from the rule allowing only a single kind of turnover tax in any Member State-an otherwise mandatory requirement derived from Article 33 of the Directive. Following an appeal, the Zala County Court [of Hungary] referred to the European Court of Justice for a preliminary ruling, which was registered under C-283/06. ${ }^{4}$ Since another reference with similar aim and content was submitted by the Supreme Court

1 77/388/EEC, Official Journal L 145, 1977.06.13. 1 (amended multiple times). Without prejudice to other Community provisions, especially general Community provisions in force on the holding, transporting, and controlling of goods subject to excise duty, this Directive shall not prevent a Member State from maintaining or introducing taxes on insurance contracts, taxes on betting and gambling, excise duties, stamp duties and, more generally, any taxes, duties or charges, which cannot be characterized as turnover taxes, given that these taxes, duties, or charges do not trigger formal requirements in connection with the crossing of borders.

2 According to the ECJ, it cannot. The local business tax is this not in conflict with Community law. Joined cases C-283/06 Közgáz and C-312/06 OTP Garancia Biztosító, European Court Reports, 2007, I-8463.

3 Notwithstanding Articles 87 and 88 of the EC Treaty, Hungary was allowed to apply, up to and including 31 December 2007, local business tax reductions of up to $2 \%$ of the net receipts of undertakings, grantable by a local government for a limited period of time on the basis of Articles 6 and 7 of Act C of 1990 on Local Taxes, as amended by Article 79 (1) and (2) of Act L of 2001 on the Amendment of Fiscal Laws, as amended by Article 158 of Act XLII of 2002 on the Amendment of Acts on Taxes, Contributions, and Other Budgetary Payments.

${ }^{4}$ Official Journal C 212, 2006.09.02. 23. 
of Hungary (which was registered under C-312/06), the president of the European Court of Justice ruled that the two cases be joined. ${ }^{5}$

Tax authorities that produced the original decisions generally prescribed in their warrant for payment that taxpayers make an advance payment of the local business tax administered via the taxpayers' local business tax account. The authorities generally founded their decisions on Paragraph (1) of Section 39 and Paragraph (2) of Section 41 of the Local Taxation Act. The public administrative agencies of second instance handling the case on appeal let the original decisions stand-as they were deemed to be correct in terms of their substance-in all cases involving Hungary. The decisions produced in the appellate proceedings were supported by the reasoning that the [Hungarian] local business tax was examined in detail as part of accession talks, and Hungary could have received the right to uphold the waivers and allowances until December 31, 2007 as part of 3(a) [on Local authority fiscal aid] of Part 4 [on Competition Policy] of Appendix X of the EU Accession Treaty. Considering the fact that the accession document does describe the institution of the local business tax (tax base, taxation rate), the public administrative agencies of second instance hold that this tax should be considered as one that would be sanctioned by the European Union as well, taking into consideration that there is no Community norm that would render the levying of this kind of tax forbidden.

Taxpayers can petition to have the official decisions changed or abrogated. They can rely on the argument that the decisions violate certain legal rules, as the obligation to pay the local business tax expired after April 30, 2004. Consequently, as of May 1, 2004 rules connected to the local business tax that are found in the Local Taxation Act can no longer be used, and in the absence of local business tax law liability, the taxpayer has no obligation to file a tax report, make an advance or regular payment connected to this tax. The taxpayer applicants may also move for the proceedings to be suspended considering that for the petition to be adjudicated the interpretation of Paragraph (1) of Article 33 of the Directive is necessary. The applicant may found his legal action that since the local business tax-which is regulated in the Local Taxation Act-is considered to be a form of turnover tax, its upholding by the Republic of Hungary has been in conflict with Paragraph (1) of Article 33 of the Directive since Hungary's accession to the European Union, i.e. since May 1, 2004, because the accession document did not contain any temporary waiver that would have enabled Hungary to maintain reliance on this form of tax.

${ }^{5}$ Official Journal C 327, 2006.09.30. 6. 
The interpretation of Community law is necessary, because if 3(a) [on Local authority fiscal aid] of Part 4 [on Competition Policy] of Appendix X of the EU Accession Treaty can be interpreted in such a way that the fact that it contains waivers connected to certain options of granting allowances related to the local business tax until December 31,2007, then this may imply that the parties have also recognized the waiver to apply to the underlying institution of local business tax itself until that day. However, if the case is that the temporary waiver contained in the accession document does not in fact apply to the institution of the local business tax form itself, then it remains open to interpretation, whether-in light of the rule contained in Paragraph (1) of Article 33-a tax is considered to be a forbidden form of turnover tax based on its relevant material characteristics, if its subject is the entrepreneur, if its scope covers all entrepreneurial activity (literally: conducting trade/economic activity, i.e. the literal meaning of the name of this tax is the tax levied on conducting trade/economic activity) conducted within the territory (i.e. jurisdiction) of the local government, in other words: all activities conducted by the entrepreneur in this particular capacity that is directed at acquiring profit or income.

The questions raised (in case No. C-312/06) by the Supreme Court [of Hungary] are to be answered individually, one by one, in other words, the national judicature would definitely like to get an answer to the question if Article 33 of the Sixth Council Directive is in fact a block in the way of upholding the aforementioned national tax. The Metropolitan Court of Budapest (in case No. C-447/06, which has by now been removed from the register ${ }^{6}$ )similarly to the question raised by the Zala County Court-also determined a hierarchical order. Accordingly, the procedural law question could only be answered in light of the outcome of the derogation and substantive law deliberations. This approach is questionable, because the procedural matter could be examined in and of itself. The reason for this-in our opinion-is that it can be considered a violation of Community law in and of itself if the public administrative authority handling the case refuses to examine whether the national tax is reconcilable with Community law, thereby forcing the taxpayer to correct his/her tax return via self-auditing, i.e. indirectly prescribing him/her a more difficult task (because this task is laden with the threat of sanctions connected to the potential finding of delinquent taxes), thereby blocking the true coming into force of Community law.

The finding of violation of procedural law may qualify as a violation of Community law-and with it a connected finding of liability on part of the

${ }^{6}$ Official Journal C 326, 2006.12.30. Removed from the register: Official Journal C 096, 2007.04.28. 29. 
Member State related to a violation perpetrated by way of legislation is possible-even if in terms of the substantive law issue (namely: "Is the local business tax reconcilable with the set Community order of value added taxation?") we could determine no finding of violation of Community law. The issue of the possible lack of reconcilability can be raised not only in general terms, based on the requirement of loyalty contained in Article 10 of the European Community Treaty, as apparent from the way the question was framed by the Metropolitan Court of Budapest. A violation of Community law on part of a national authority, or that of national law actually means the violation of Article 33 of the Sixth Council Directive, because the issue of reconcilability of national taxation with harmonized value added taxation can only be raised in a proceeding that by its nature presents a burden for the taxpayer. The prohibition contained in Article 33, according to which Member States are barred from introducing a national tax not reconcilable with harmonized value added taxation, can only be fully functional, if at the same time citizens are guaranteed the opportunity for Community law violations to be recognized (identified) without any disproportionate burden before national authorities, and similarly their connected rights are freely exercisable in actuality.

\section{Impediment to the enforcement of Community law}

The local business tax is of a hybrid nature: it is based on self-assessment tax payment [Paragraph (1) of Section 25 and Paragraphs (1)-(2) of Section 26 of the Act on the Rules of Taxation], but also has the proceeding of an official authority ending with a decision inserted into the process of self-assessment taxation. The warrant for payment describing the amount of tax advance to be paid is the product of an official proceeding, and according to Section 123 of the Act on the Rules of Taxation, the payment order qualifies as an authoritative decision, which produces a result directly connected to the significant material subject of the tax related case, therefore the option of petitioning for a review of the legal issues connected to the case must be guaranteed for the client without any limitation. The authority of second instance violates the law if it declares that it has no capacity to rule whether the original mode of levying the tax was lawful or not. The fact that according to Paragraph (5) of Article 41 of the Local Taxation $\mathrm{Act}^{7}$ the tax authority determines the amount of the tax advance to be paid based on the annual tax report filed by the taxpayer, does not lead to the conclusion that the tax authority is released from the

\footnotetext{
7 The tax authority issues a warrant for payment to communicate the amount of tax advance to be paid, determined based on the annual tax report or the reporting of projected tax.
} 
obligation to examine the legal issues connected to producing a decision that declares the imposition of the tax. This is so, because Paragraph (1) of Section 31 of the Act on the Rules of Taxation ${ }^{8}$ contains guidance relevant to the content of a tax report, according to which the document contains data necessary for both the determination of the tax, and that of the (legal) foundation of the budgetary support, and its sum.

According to Paragraph (3) of Section 41 of the Local Taxation Act, if the base or rate of the tax changes due to a change made in a legal rule, then the public administrative authority must determine the new sum of the tax advance by taking into account the updated formula and/or rate of the given tax. In the previously mentioned litigation, this is exactly what was observed: a change in the legal rule occurred, effective on the day of accession, specifically: the incompatible Hungarian rule (requiring the payment of the local business tax, which is irreconcilable with the harmonized value added taxation system) was replaced directly by the Community legal rule, and in truth this should have been noticed by the public administrative authority handling the case, and accordingly, the authority should have declared the expiration of the obligation to pay this tax.

Considering that the taxpayer applicant initiated legal proceedings directed at challenging the legality of the tax liability [citing Paragraph (3) of Section 41 of the Local Taxation Act in support of applicant's claim] and also challenging the base and rate of the tax [citing Paragraph (1) of Section 31 of the Act on the Rules of Taxation], the tax authority may not decline to take a position in the connected legal debate, which is an issue otherwise independent from the declarations provided by the taxpayer in taxpayer's annual tax return. In this aspect it is also irrelevant that the production of the decision was not preceded by a tax administrative proceeding. If the tax authority becomes aware of the violation of Community law resulting from the change in the legal rule, it must initiate the abrogation of legal rules establishing the obligations connected to the local business tax. As a result of this, the taxpayer status in this respect will cease to exist, since the taxpayer is defined as the person who has a liability for tax, and this status is, on the other hand, defined by a piece of legislation currently in force [namely: Paragraph (1) of Section 6 of the Act on the Rules of Taxation].

If the public administrative authority was to produce a decision only regarding the numerical issue [of size], then there would not even be need for a decision that determines rights and obligations. However, as part of the process

8 The tax report contains data necessary for determining the identity of the taxpayer, the tax base, exemptions, reductions, and the amount and basis of budget support. 
of producing a decision, the authority may not decline to take the responsibility of forming an opinion of its own regarding the legitimacy of the legal basis for levying the relevant tax, especially if such a close examination is expressly requested by the taxpayer. According to the law, the public administrative authority is understood to be producing a formal decision even by the mere act of exercising its power to issue an official certificate or identification/registration document, or when deciding as registrar to enter someone into an official registry under its administration. If the taking of responsibility for deciding underlying legal issues cannot be avoided even in these more routine and mundane situations, it is certainly unavoidable in cases connected to levying taxes, even if in this particular case we are only faced with the issue of fixing the size of an advance payment of tax based on self-reporting.

The position of the authority, according to which the decision declaring the levying of the tax contains no obligation beyond that of the numerical definition of the tax liability, can be considered erroneous. On the one hand, according to Paragraph (1) of Section 42 of the General Rules of State Administrative Procedure Act (Áe.) [no longer in force, as replaced by Ket.] or Paragraph (1) of Section 71 of Public Administrative Procedure and Services Act (Ket.), the authority produces a decision in cases of merit, on the other hand, the adjudication of the merits of the case cannot happen without producing a decision. The decision produced by an authority has to contain not just the statements of facts, but has to also cover the legal foundation of the decision. When producing an authoritative decision, the public administrative authority handling the case may not refuse to conduct the task of examining the lawfulness of setting an obligation contained therein. If the taxpayer chooses to challenge the public administrative decision declaring the taxpayer's obligation to be liable for taxes levied, then the lawfulness of the liability for taxes cannot be determined just by examining whether the taxpayer did in fact file a return and with what content, but in certain situations the review should also cover the examination of the question whether the legal rule supposedly serving as the foundation of the tax reporting is in fact valid or not. This latter examination is independent of the question of whether or not the taxpayer challenges the tax connected to his or her tax report.

If the taxpayer applicant launches a legal challenge regarding the lawfulness of the liability for a given tax, then the taxpayer's intention is not to minimize the risk of being in error, rather the taxpayer wishes to avoid the lack of the rule of law, without having to suffer certain adverse consequences (undue burden) should the decision in the case eventually go against him/her. But this is exactly the situation the taxpayer is forced to be faced with in such a tax administrative system, where one cannot file a tax report with reservation. 
If the public administrative authority of second instance takes the position that it can only conduct an examination of the lawfulness of the local business tax if the taxpayer files a return in conjunction with the taxpayer claiming that the local business tax is not in harmony with Community law, then the authority forces the taxpayer to take the risk of initiating a legal challenge with the threat of sanctions hanging over his/her head connected to the possible finding of delinquent taxes. This conduct of the authority results in the taxpayer being seriously harmed in exercising his/her rights granted by Community law.

The taxpayer applicant's such conduct cannot be deemed unlawful nor can it he/she be considered to be acting in bad faith, and neither can the taxpayer's tax report be considered baseless, unless such circumstances are confirmed by a final ruling in the given case by a public administrative authority having appropriate power and jurisdiction. Since no such instance could be detected, there could be no doubt that applicant's conduct concerning the matter forming the subject of the lawsuit was lawful. Had the defendant had certain questions about the lawfulness of the tax liability, then it would have had the chance to, for example, suspend the public administrative authoritative proceeding, and then it could have proceeded to resolve the underlying issue. Even though the applicant moved specifically requesting the authority to do just that, the defendant refused this motion. If the defendant simply takes, duly notes, and processes the applicant's tax report without any special consideration, then the defendant's conduct can be considered unlawful, if-at the same time-it fails to examine-even as a self-assigned task, by default, on its own volition-whether the relevant legal rules are in fact in force, and whether the liability for taxes forming the basis for the tax report is in fact in accordance with the law.

Naturally, the subject of the proceeding does not get rendered obsolete, nor can the proceeding be terminated even in the presence of the taxpayer's such positive declaration, or similar positive act (as the filing of an annual tax report), which results in the actual payment of taxes. In a public administrative authoritative proceeding it is an obligation of the authority-either by request or in its official capacity, by default-to guarantee lawful law application, and to support the enforceability of the law, including that of Community law. The authority's obligation to render an authoritative decision regarding the lawfulness of the liability for tax is prescribed by law, with no regard to the filing of a tax report for a given tax year. If the taxpayer chooses to challenge the public administrative decision declaring the taxpayer's obligation to be liable for taxes levied, then the lawfulness of the liability of taxes cannot be determined just by examining whether the taxpayer did in fact file a return and with what content, but in certain situations the review should also cover the examination of the question whether the legal rule supposedly serving as the 
foundation of the tax reporting is in fact valid or not. This latter examination is independent of the question of whether or not the taxpayer challenges the tax connected to his or her own tax report.

The defendant public administrative authority may argue that it had examined the legal issues raised by the taxpayer, and conclusions connected to the underlying legal issue were appropriately represented in the opinion. However, since the defendant public administrative authority of second instance took the position that the local business tax was in fact not irreconcilable with Community law, it ruled against the petitioner taxpayer. The public administrative authority merely mentioned in passing in its decision as a possibility, that the applicant taxpayer may correct his or her tax report via self-auditing (by submitting a zero return). If this in fact does take place, then the public administrative authority may conduct an examination in the form of a tax administrative proceeding that covers the lawfulness of the local business tax. However, in view of the defendant authority it (the public administrative authority) is bound during the review of the decision prescribing the payment of tax advance to the tax report filed, and that is why it cannot declare, in contrast with the tax report, that the taxpayer has no liability for local business tax.

Thus, in view of the public administrative authority, the opportunity is open to examine the question of lawfulness of the local business tax only if the taxpayer corrects his/her tax report by way of a self-audit (i.e. by filing a zero return). This is a procedure of the authority, which equals the violation of the taxpayer's rights protected by Community law, and one that results in the authority blocking the taxpayer exercising his or her rights. Since as part of the review of the decision containing the payment order, the public administrative authority refused to examine the lawfulness of the local business tax in the way described previously, it was immaterial that, on the other hand, it did refer to the taxpayer's argument as part of the opinion of the decision, and that it also included its related evaluative reasoning, these latter factors have no significance when examining the lawfulness of the authoritative decision. This is so because the authority based its reasoning on the assumption that it is tied by the tax report, and that is why it has no option to examine the lawfulness of the local business tax, and it cannot, by default, reach any conclusions that would be contrary to the tax report. Naturally, it is questionable, however, that the public administrative authority is in fact bound by the tax report, since a public administrative proceeding is inserted into the process of taxation, which produces an authoritative decision. Due to the fact that, as a result of the public administrative authority's destructive stance, the authority's procedure blocks the taxpayer in exercising his/her rights relevant from the perspective of Community law, we observe a violation of Community law-a matter that is 
to be examined in and of itself. Therefore, even if the substantive law rules of the local business tax were found to be in harmony with Community law by a national court or the European Court of Justice, the legal violation described above would be reason enough to find that the public administrative decision was unlawful.

Another hypothetical question is raised by the following scenario: the taxpayer files a zero return, but pays the tax anyway, in order to avoid having delinquent taxes. This scenario, however, is not permissible by Hungarian law currently in force, because the correction of data provided regarding the tax or the tax base triggers the obligation to make a corresponding tax payment, since the corrected tax amount becomes due with the filing of the matching report [(1) of Section 51 of the Act on the Rules of Taxation]. ${ }^{9}$ Thus, it is not possible that a tax payment obligation reported after a self-audit be separated in time from the actual payment becoming due. It is generally true of Hungarian law, that the filing of a tax report and the connected materialization of the obligation to make a tax payment is inseparable from this same obligation becoming due. It is true that overpayment is possible, and the taxpayer may-under certain circumstances-require the refund of the surplus payment [(6) of Section 43 of the Act on the Rules of Taxation $],{ }^{10}$ in the albescence of such request, however, the tax authority may cancel the amount of overpayment acting in its own official capacity once the allotted time reserved for such claim has expired [(5) of Section 43 of the Act on the Rules of Taxation]. ${ }^{11}$ When we claim that the obligation to pay tax becoming due is different from the materialization of the obligation, we are in other words saying that the flow

\footnotetext{
9 The amount of corrected tax, the budget support, and the assessed self-auditing extra charge is due at the time of their reporting.

${ }^{10}$ If the taxpayer has no tax debt, the taxpayer may request repayment of the remainder amount. In absence of such express request, the tax authority will treat the excess amount resulting from the overpayment as credit, and will automatically use it toward settling taxpayer's future tax obligation. The local tax authority may return the excess amount only on condition that the taxpayer at the time has no unsatisfied payment obligation of any public charge collectible [to be collected] as tax in its records.

${ }^{11}$ If the taxpayer or the person obliged to pay the tax [(2) of Section 35] paid an amount exceeding the amount that would have correctly been due for the given tax obligation (overpayment), the tax authority shall use the excess amount to settle other taxes due by the same taxpayer according to its records, provided that the taxpayer request such reassignment. Once the legally allotted time has passed for the taxpayer to request a refund, the tax authority automatically reassigns the remainder amount to settle other outstanding tax debt of the same taxpayer on its records, or in absence of such outstanding debt it officially removes it from its records. A tax payment made in error to the wrong bank account of the same tax authority is to be treated as a payment obligation satisfied.
} 
itself of a tax payment and the materialization of the obligation to pay a tax do not necessarily coincide, similarly to how in economic life we see that acts of delivery (of goods) or rendering of services (i.e. e.g. one party fulfilling its contractual obligations) do not necessarily have to coincide with payment becoming due.

An overpayment can reduce the amount of delinquent tax (back tax) [(2) Section 170 of the Act on the Rules of Taxation], ${ }^{12}$ but it cannot, on the other hand, have an effect on the finding of tax discrepancy. The tax discrepancyi.e. the difference between the amount of tax to be paid according to the finding of the tax authority and the amount of tax reported, or the amount omitted from the tax return [3. Section 178 of the Act on the Rules of Taxation $]^{13}$-is the category, which has to be in sync with the materialization of the obligation to pay tax, independent of when the payment obligation becomes due, or how much tax had actually been paid already. Since according to Hungarian law currently in force, the reporting of liability for tax on part of the taxpayer cannot be separate from when the obligation to pay becomes due, there is no option to file a tax report without prejudice, furthermore, the taxpayer is even prohibited form exiting the domain of self-assessment taxation and instead request that taxes be assessed by the tax authority. Self-auditing can only be used in case the original tax return was not in accordance with some legal rule or contained erroneous figures or calculative errors.

According to the solidified practice of the European Court of Justice, any legal rule or authoritative practice of national law that can have the effect of weakening the exercise of rights protected by Community law by taking away the liberty of the authority handling a case to do everything in its own power to facilitate the working of Community law, qualifies as a material violation of Community law. ${ }^{14}$ According to the view of the European Court of Justice, and the taxpayers registered in the United Kingdom, taxpayers cannot be lawfully forced to request a tax exempt status in relation to the obligation to pay

${ }^{12}$ A tax discrepancy assessed to the taxpayer is to be considered a tax shortfall, but in the case of self-assessment taxation this is true only if the amount of the tax discrepancy was not settled before the time it was due, or if the budget support was taken advantage of. An overpayment existing at the time of the original due date can only be considered as the meeting of the tax payment obligation, if the overpayment also exists on the day of commencement of the audit.

${ }^{13}$ See "tax difference: the difference between tax reported, failed to be reported, or levied/assessed based on reporting, and tax or budget support subsequently determined by the tax authority; or tax revenue deficit found in the final judgement of the criminal court; or budget support taken advantage of without entitlement."

${ }^{14}$ C-118/00 Gervais Larsy v. Inasti, European Court Reports 2001. I-05063. 51. 
the advance on corporate tax, triggering the likely reaction of the tax authority, which consequently finds the delinquent taxes and applies the connected sanctions [of penalties or added interest obligation]. While it is true that the decision containing the sanction can be challenged on appeal before a court of law, in view of the European Court of Justice it is a serious block in the way of exercising rights provided by Community law if the taxpayer has to face the probability of the negative decision of the tax authority. ${ }^{15}$

The blocking of the effective use of rights protected in Community law is a serious legal violation in and of itself, therefore this issue can be adjudicated independently of the substantive law issue, moreover, the defendant can be found to be responsible for the violation even if otherwise the local business tax could not be proven to be irreconcilable with Community law. The reason for this is that as part of the original proceeding the applicant requested that the scope of the issues proposed for deliberation in connection with Article 33 include not only the substantive law but the procedural law aspects as well, and found it necessary that the European Court of Justice declare its position regarding the procedural issue as well.

\section{Damages caused with legislation (by the local business tax, which violates Community law)}

\section{Background}

According to one possible position based on Paragraph (1) of Section 339. of the Civil Code of the Republic of Hungary (Act No. IV of 1959 as amended; " $\mathrm{CC}$ " in the following) it is possible to bring legal action against the Hungarian State as defendant for damages caused with legislation. The applicant's damages equal the amount of local business taxes due since the May 1, 2004 accession of Hungary to the European Union, which were paid according to legally binding public administrative authoritative decisions in due course, but which the taxpayer would not have been obliged to pay had the Republic of Hungary not kept the legal rules in force mandating the payment of the local business tax violating Community law.

The applicant can move to initiate preliminary ruling proceeding for the purpose-among other things-of interpreting if maintaining the local business tax is in conflict with Article 33 of the Sixth Council Directive after accession. The question had also been raised whether 3 a) of Part 4 of Appendix X. of the

\footnotetext{
${ }^{15}$ Joined cases, Metallgesellschaft, Hoechst, 107.
} 
accession document could be interpreted in such a way that it provides a temporary period of waiver for the Republic of Hungary from the obligation derived from Article 33 of the directive, to maintain only a single kind of tax based on turnover. Another issue raised in connection with the interpretation of Paragraph (1) of Article 33 was whether it is a possibility consistent with Community law that the public administrative authority of second instance declines to examine the reconcilability of the local business tax with Community law, unless the taxpayer files a tax return in such a way that it includes a reference to the supposed lack of valid tax payment liability, thereby taking on the risk of sanctions connected to the finding of delinquent taxes. This is of importance because in this latter scenario the tax authority handling the matter is instrumental in setting the taxpayer on a course of a tax administrative proceeding with an uncertain outcome, which blocks the taxpayer from exercising his/her rights, and consequently impedes the actual functioning of Community law. According to the national court in charge of case No. C-447/06-the Metropolitan Court of Budapest-the applicant's motion to initiate the preliminary ruling procedure (detailed above) had legitimate basis. (The case had been removed by the European Court of Justice from its records, due to the fact that the decision brought at the lower level was later changed on appeal.)

\section{Legal basis of the compensation claim}

Since the issue (of a compensation claim for damages caused with legislation by a Member State) raised by the applicant's original legal action is of a sort, for which the European Court of Justice has developed a separate standard practice, the need for interpreting Community law is presented by this particular case as well. Simultaneously with filing applicant's lawsuit, applicant first and foremost initiated that the national court produce a preliminary ruling on how to interpret Paragraph (1) of Article 33 of the Sixth Council Directive with respect to the question of whether or not the local business tax kept in force by Hungary following its accession is reconcilable with Community law. Applicant's damages are not only attributable to having had to pay the local business taxin a way that violates Community law-, but is also connected to the fact that the Hungarian legal system in force failed to produce an environment, where the access to Community rights is not significantly burdensome. For the legal conflict to be resolved, it is necessary to call upon the European Court of Justice to provide an interpretation of Paragraph (1) of Article 33 of the Sixth Council Directive, which deals with harmonized value added taxation. With regard to this, we not only see the question raised whether or not the rules contained in Paragraph (1) of Article 33 of the Sixth Council Directive and 
rules governing the local business tax (as per Chapter IV of the Local Taxation Act) are in harmony, but also whether the respondent's position claiming that there is no possibility of changing or ending the obligation to make an advance payment on the local business tax until (and unless) the taxpayer files a corrected tax report based on self-auditing is consistent with Paragraph (1) of Article 33.

The liability of a Member State for damages can be connected technically with the "loyalty clause" of the European Community Treaty (Article 10.). This is exactly the root of the liability of a Member State for violating Community law. We should, at the same time, point out that compensation for damages is the most general form of sanction applied by the European Court of Justice. The reliance on this sanction has implications regarding the entirety of a national legal system, because it can be seen as the most appropriate tool of implementing rights enforcement in a rule-of-law environment and a market economic framework. This is because the prime importance of the sanction of compensation can be explained, first and foremost, by the fact that citizens' rights are protected by law, and the violation of these rights can be interpreted as a financial matter. Consequently, a prerequisite of an compensation claim is the definition of damages in financial terms. The compensation claim is not primarily connected to harm caused to the property or financial holdings of citizens, rather it is viewed as the most generic tool of rights enforcement in case of rights violations. This has a significance in determining liability for damages in individual cases as well, since the civil court charged with protecting the existing legal order has the capacity to rely on the use of compensation claims in any case, in which the court finds the harming of rights in connection with any legal relations.

In connection with the delictual liability of Member States for the violation of Community law, the European Court of Justice has found in the Francovich case ${ }^{16}$ that the comprehensive enforcement of Community legal rules would be impeded if private citizens could not have access to legal redress, if their harm was caused by a rights violation attributable to a Member State. According to the European Court of Justice, the principal, according to which a Member State is liable for damages caused to private citizens by a violation of Community law that is attributable to that state is rooted in the internal system of the Rome Convention. In consecutive years,${ }^{17}$ the European Court of Justice further refined

${ }^{16}$ C-6/90, C-9/90 Andrea Francovich, Daniela Bonifaci \& others, combined case, European Court Reports 1991. I-5357, Para. 33.

${ }^{17}$ C-46/93, C-48/93 Brasserie du Pêcheur, Factortame Ltd. \& others, combined case, European Court Reports 1996. I-1029, Para. 51. 
the criteria of finding delictual liability for national legislation not consistent with Community law, which are the following:

- the piece of Community law at issue was originally intended to give rights to individuals

- he violation of Community law alleged to have been committed by a ber State is significantly harmful

- here is a cause and effect relation between the Member State's failure fulfill an obligation and the harm.

According to the solidified position of the European Court of Justice (C46/93 Brasserie du Pêcheur, C-48/93 Factortame, Para. 74), the adjudication of the compensation claim is to be carried out by the national courts by way of applying the rules of national law, and the execution of the claim may not be burdensome (efficiency requirement), and the relevant legal rules may not be less favourable than other national legal rules relevant to the adjudication of other (types of) claims for damages (equivalency requirement). ${ }^{18}$ An alternative of the compensation claim can be the petition for a restitution claim (C-397/98 Metallgesellschaft, C-410/98 Hoechst, Para. 77). When petitioning for a restitution claim, the applicant need not give proof of the existence of each prerequisite criteria of the compensation claim, and an additional concession providing a lower threshold is that in the context of Community law there is no need to give proof that the violation of Community law was significantly harmful (C46/93 Brasserie du Pêcheur, C-48/93 Factortame, 56-57). In contrast, however, the scope of the restitution claim is limited relative to that of the compensation claim, in that, for example, disadvantages connected to the harm caused (such as, for example, the weakened position of the enterprise affected by the national legal rule that violates Community law) may not be included in the restitution claim. In Hungarian law, the possibility of petitioning for a restitution claimas a claim for damages-is possible by referencing Section 6 CC. ${ }^{19}$

Generally, the European Court of Justice, when adjudicating a case, does not tend to get involved in deciding how the object of applicant's petition can be categorized within civil law. This is due to the fact that according to the view of the European Court of Justice, it is a matter belonging to the scope of

${ }^{18}$ See also: C-231/96 Edis, European Court Reports 1998. I-04951, Para. 34. A Member State may reasonably determine a short period available for a [taxpayer] to enforce a claim for the refunding of a payment of a common charge that was assessed unlawfully, which, however, may not make the actual enforcement of rights guaranteed by Community law burdensome (Edis, Para. 35).

${ }^{19}$ The court may oblige a person to pay damages in part or full, whose wilful conduct caused another person acting in good faith to perform an action with good reason that caused him or her harm through no fault of his or her own. 
national law, if a particular case is based on an compensation or a restitution claim (C-397/98 Metallgesellschaft, C-410/98 Hoechst, Para. 81, C-446/04 FII Group Litigation, Para. $203^{20}$ ). In any case, the applicant's demand may only legitimately include those particular damage items that are directly connected to the damage caused by the Member State's violation of the law. Accordingly, for example, the forgoing of one special tax allowance (in connection with the taking of another tax allowance), or, for example, the paying of an increased dividends payment in order to compensate for the unavailability of a tax allowance are not sufficient grounds for requesting compensation for damages (C-446/04 FII Group Litigation, Para. 207). In the litigation concerning the local business tax, it is clear that the applicant's petition included a restitution claim, referring to the fact that all prerequisite criteria prescribed by Section $339 \mathrm{CC}$ in connection with the finding of liability for damages were present. Furthermore, applicant's claim only covered damage items directly connected to the damage claim (as the applicant's claim covered only the amount paid in taxes that should not have been paid had the Republic of Hungary not demanded this payment in a way that violates Community law, plus the applicant's claim obviously also covers the payment of interest on the amount that had actually been paid by the applicant).

\section{Unlawfulness and imputable conduct}

Based on the above, we believe that the finding of liability for damages on the part of the Republic of Hungary is well founded. Based on Paragraph (1) of Section 339 CC, there is a legitimate claim against the Hungarian State for the compensation of damages caused by wrong legislation. The taxpayer applicant's damages equal the amount of local business taxes that were due for the period following the date of accession, and which were paid according to the enforceable decision handed down by the authority, but which would not have had to have been paid had the Republic of Hungary not kept these legal rules on the local business tax in force after accession, which has been a violation of Community law. The Republic of Hungary committed a violation of Community law-therefore the liable Hungarian State's conduct is unlawful-by way of keeping in force certain legal rules on local business taxation as part of Chapter IV of the Local Taxation Act, that are not reconcilable with the Sixth Council Directive on harmonized value added taxation. The Republic of Hungary is culpable (her conduct is imputable) in causing the damages, because it failed

${ }^{20}$ European Court Reports 2006. I-11753. 
to request derogation regarding Article 33 of the Sixth Council Directive on the uniform structure of value added taxation, and additionally, because it failed to examine with due diligence, whether the maintenance of this tax will result in the violation of Community law following accession.

International practice shows that immunity of the state in developed countries is understood to be a differential matter, where "iure imperii" and "iure gestionis" of the state's jurisdiction are strictly separated. Considerations akin to these were driving the revision of the CC's rules concerning liability for damages, when following the political changes in 1990, rules protecting state immunity were abrogated. ${ }^{21}$ With regard to unlawful conduct, the Supreme Court of the Republic of Hungary took the position in a case earlier this decade (Court Ruling 264/2002) that no civil law damage claim can be made in connection with liability connected to the act of passing legislation, because the causeand-effect relation between the erroneous legislation and the suffering of harm does not produce any detectable civil law relation between the legislator and those who are perceived to have suffered certain negative consequences. The civil court cannot find that the legislator committed unlawful conduct by failing to produce certain legislation, an act challenged for it being allegedly of negative consequences. The court must, however, change its juridical course after accession, since the clear practice of the European Court of Justice has shown that unlawful conduct is understood to be present, even if the violation of Community law occurs by way of legislation.

The Supreme Court arrived at the position (e.g. Court Ruling 312/1994) regarding the liability of legislators, that the damage connected to the enactment of the legal rule, that legislation as an act of producing general and abstract rules of conduct, and the connected liability are covered by the scope of public law, which according to Hungarian law guarantees immunity for the legislators. However, according to the practice of the European Court of Justice, the damage can be understood to be of an individual nature, and any subject of a national law has the capacity to petition for the compensation of damages caused by legislation violating Community law. Should there be no availability of a possibility to do so, this shortcoming of the national legal system would constitute a serious hindrance in the way of the practical enforcement of Community law.

The practical workings of a democratic rule of law state has burst the traditional boundaries of the liability for damages of the state and the viability of connected claims, because according to the traditional framework, legal responsibility could only be found if

${ }^{21}$ 94/V/200. [Hungarian] Supreme Court decision, dissenting opinion, III. 3. 
- the damage was caused by a public administrator, by way of violating professional rules of conduct, or failing to fulfill responsibilities ascribed to him or her

- the damage caused can be interpreted as the withholding of advantages available to (individually) separate third persons.

According to Subsection (1) of Section 339 CC, the causing of damages is always unlawful, unless it is expressly lawful. This is a true statement independently of the legal (subject) status of those who have caused the damage. A positive discrimination granted to the state by way of the legal system sanctioning that the state need not necessarily act responsibly (i.e. allowing that it not be held responsible), is in conflict with Section 70/A of the Constitution [of the Republic of Hungary] prohibiting negative discrimination. In the given case we may also be able to infer the abuse of legislative power, the legal source of which is Subsection (1) of Section 2 of the Constitution.

According to the practice of the European Court of Justice, if a Member State violates Community law by way of legislation, it cannot make its legal accountability conditional on the particularities of its division of branches of power. The state's liability for compensation cannot be limited to some state administrative act. ${ }^{22}$ In modern legal practice the state's liability for the violation of international or Community law must be perceived as a uniform whole, regardless of the fact whether the violation has occurred in connection with the legislative, the executive branch, or the judiciary (Brasserie du Pêcheur, Para, 34). Citizens cannot be blocked in their ability to enforce their rights or have access to judicial redress if they reference Community law, even if the damage caused is attributable to national legislation violating Community law (Para. 35).

Bringing the state to legal account in connection with damages caused by legislation is possible if

- the legislator of the Member State had a wide range of evaluative (discretionary) power when it introduced the national legislation; there would have been a possibility to carve out individual rights based on the Community right violated, and the violation of Community right is significant; and

${ }^{22}$ C-179/94 Brasserie du Pêcheur, 33; C-188/94, C-189/94, C-190/94 Erich Dillenkofer, Christian Erdmann, Hans-Jürgen Schulte, Anke Heuer, Werner, Ursula and Trosten Knor, European Court Report, 1996. I-04845, Para. 29. The obligation of a Member State to indemnify a damage is valid even if the damage occurs because the national court brought a final judgement violating Communnity law, where Community law prescribes rights individually enforceable by citizens. C-224/01 Gerhard Köbler, European Court Reports 2003. I-10239, Para. 59. 
- there is a cause and effect connection between the violation of the Community right and the damage caused to citizens.

The responsible Member State must offer legal redress within the framework of its own legal rules. However, these rules cannot be less favorable to the harmed party than those guaranteed in connection with legal violations by the internal rules (of the Community), and under no circumstances can the national rules make the enforcement of these rights disproportionately more difficult (Para. 74).

Stockholm Lindöpark AB sued the Swedish State because until 1997 the latter kept in force a certain value added taxation rule in conflict with the Sixth Council Directive, according to which the letting of immovable property for the purpose of practicing sports is a service exempt from VAT-even if this purpose is amateur sporting activity-, consequently the related 'transferred' tax cannot be deducted. When seeking damages, the taxpayer set its demand for compensation as being equal to the amount of 'transferred' tax (indirect tax shifted to the lessee) it could not deduct during the term between the date of accession of the Kingdom of Sweden (January 1, 1995) and the amendment of the relevant legal rule (January 1, 1997). The Court ruled that due to the fact that the Swedish legal rule was not in harmony with Community law in the two years following the country's accession, the Kingdom of Sweden committed a serious and obvious legal violation by infringing Community law, which is sufficient grounds for finding the validity of the state's liability for compensation. $^{23}$

The damage caused by way of legislation is chargeable to the person causing the damage, because the Republic of Hungary could have asked for the implementation of temporary rules in connection with Paragraph (1) of Article 33 of the Sixth Council Directive, by referring to the local business tax, which it failed to do, even though it did ask for-and was granted-derogation in connection with Paragraph (3) of Article 12 of the same directive (Para. 6 of Part 7 on Taxation of Appendix X. of the accession document). Since the legal debate concerning the local business tax was launched immediately following accession, the Republic of Hungary could have had the opportunity to request a preliminary investigation from the European Committee. However, the Hungarian State causing the damages failed to gather the necessary information, (and this is legally ascribable to it), thereby upholding a state that violates Community law, and has done nothing concrete anyway in order to resolve the issue. Regardless of this, according to the clear practice of Community law, if the condition is present that the damage caused by way of legislation is sig-

${ }^{23}$ C-150/99, European Court Reports 2001. I-00493. 40. 
nificant-and in the Hungarian case this is naturally so-the state's liability for compensation for damages cannot even be made dependent on the examination of culpability according to the European Court of Justice (Brasserie du Pêcheur, Para. 80).

Prior to May 1, 2004, the Republic of Hungary categorized the local business tax as a type of value added tax. ${ }^{24}$ Despite this fact, the Republic of Hungary failed to reconcile the relationship of the local business tax and the related Community law in any finite manner during accession talks. Hungary did not ask for-and therefore did not receive-derogation for the local business tax in connection with the Sixth Directive. Based on this, its action can neither be considered lawful, nor prudent, and neither can we determine that it was acting in good faith.

The Republic of Hungary decreased the standard rate of the value added tax (áfa) from $25 \%$ to $20 \%$ by enacting Act No. XCVII of 2005 (see Section 1). However, in order to offset the budget deficit that would have been caused by the independent introduction of this measure, it decided to overrule its previous decision to end the institution of local business taxation. In formal terms this meant that the legislation abrogated Section 190 of Act No. XCIX of 2005which would have ended local business taxation as of December 31, 2007-by enacting Section 236 of Act No. LXI of 2006, which struck the legal rule that mandated the ending of local business taxation. Considering that the Republic of Hungary viewed the local business tax as one that could be used to supply revenue for the state, which could be expected to balance the budget in terms of the revenue lost due to decreasing the general rate of value added taxation, we may come to the conclusion that the value added tax is in fact comparable to the harmonized value added tax that exists in the European Community.

\section{Injury suffered}

Although it is normal that the burden of the local business tax, expressed in monetary terms, is passed on to the consumer (or client), this does not mean that the payment of the tax, which violates Community law, did not in fact cause damage to the applicant itself. This is because we must-on the one hand-take into consideration the fact that the financial advantage gained by passing on the financial burden of the tax is not demonstrable by exact calculations, cannot be represented in monetary terms,--and on the other hand-if in fact the tax is a cause of price increase, then this is a cause of decreased competitive-

${ }^{24}$ Opinion of the Ministry of Finance of the Republic of Hungary, May 30, 2002. (No. 6479/6/2002.) 
ness, since it is uncertain whether the taxpayer is capable of passing on the damage in a particular case, and if it can, then to what extent and with what conditions attached. Consequently, we cannot demonstrate a direct connection between the general trend of passing on the respective amount of the tax and the potential decrease of the damage on part of the taxpayer (i.e. we cannot come to a well-founded conclusion that the damage caused by the payment of the tax has potentially decreased). The passing on of the tax burden is conditional on several factors, which cannot necessarily be connected to the passing on of the damage. Even if the passing on of the tax does in fact occur, there still remains a question as to what the passing on of the tax is attributable to, because the relevant circumstances can be different from one case to the next.

What we can state as positive fact is that the tax had to be paid and the obligation would not have burdened the taxpayer had the Hungarian State been prudent in its course of action following accession, and thus would have brought its law in line with Community advancements. In this respect, we may also state that applicant's damages are unconditional, singular and countable. It is certain that tax had to be paid. It is uncertain how this burden could have been passed on-if at al-, because it cannot be directly connected to a pecuniary advantage that can be defined in terms of civil law damage liability. This would only be possible, if the tax could in fact be listed as a line item on the invoice, and the tax burden could not be listed as expenditure on the books, (as is the case with the value added tax, where the tax to be paid is not considered to be revenue, and the deductible tax is not considered to be an expenditure). We could only make a well-founded and exact conclusion that the damage is being passed on from the fact that the tax is being passed on if the tax burden existed in a closed system. In this case, however, this is not so, since the calculation of the tax to be paid and the tax that can be deducted cannot be separated in book-keeping terms from how the financial results (revenues and expenditures) materialize.

This latter circumstance does not, as a matter of fact, make it questionable that the tax is materially (practically) transferable to the client, and is thus functionally comparable to the [Hungarian] value added tax [áfa]. In a paradoxical way, in order to compare with the harmonized value added tax, it is only necessary to show that the taxpayer is capable of passing on the tax burden to the consumer (or client)-so long as the base of the tax is the gross revenue-; however the financial advantage gained by the ability to pass on the tax can only be validly shown to exist, if the tax is separable from the system of revenues and expenditures, and can be listed separately on the invoice as well. As a point of fact, it follows from the functional approach to the local business tax that it is theoretically within the realm of possibilities to find the 
irreconcilability of the local business tax with Community law even if the local business tax and the harmonized value added tax are not comparable in terms of the transferability of the tax. Consequently, the national court could even reach the conclusion that the local business tax is not transferable, nevertheless, it is not reconcilable with harmonized value added tax. In this case, however, the possibility of mitigating the damage connected to the payment of the tax does not even enter the picture.

The European Court of Justice made a declaration of guiding importance in the San Giorgio case, according to which it is not consistent with Community law-as it is an obstruction in the way of satisfying a damage claim-if a national legal rule contains such protections, or prescribes such rules of evidence, which-when applied-put the burden on the taxpayer to prove that the burden of paying a tax violating Community law could not be transferred to other persons..$^{25}$ A national legal rule (necessarily) violates Community law, according to which the rules prescribing indirect taxation themselves could be bases for concluding that the tax is transferable, unless the taxpayer proves the opposite. ${ }^{26}$ According to the European Court of Justice, the right to petition for the reimbursement of taxes paid based on taxes levied in violation of Community law is a right organically and inseparably attached to substantive rights guaranteed by national or Community law. ${ }^{27}$

Even if national law makes it possible to transfer (pass on) the burden of a tax (as an indirect tax) to the consumer-and there is in fact a trend to do so in commercial practice-, it is not necessarily possible to presume that this actually does take place in every case. Whether or not the partial or complete transfer does in fact happen can be conditional on a lot of different factors. Consequently, the issue of transferability is an issue of fact, or more precisely the issue of whether the Member State causing damage by way of legislation

${ }^{25}$ 199/82, European Court Reports 1983. 3595, Para. 14.

${ }^{26}$ C-343/96 Dilexport, European Court Reports 1999. I-579, para. 54.

${ }^{27}$ 309/85 Bruno Barra, European Court Reports 1988. 355, Para. 17. The attempt to recover the amount of a tax payment made cannot be blocked by-for example-requiring that the burden of proof rest with the taxpayer in absence of official book-keeping records prescribed by the Accounting Act. C-129/00 Commission v. Italy, European Court Reports 2003. I-14637, Para. 37. Similarly, the fact that a taxpayer commercial enterprise lists the amount to be recovered [via the refunding of tax] among recievables on its balance sheet in the tax year when it paid the tax demanded unlawfully, does not allow the conclusion that the enterprise did so because it passed on the relevant cost to the consumer (Para. 40). It is not reconcilable with Community law if the practice of the competent authorities of a Member State based on this or similar logic makes it burdensome to enforce a claim for the refunding of taxes paid based on an unlawful obligation (Para. 40). 
violating Community law is capable of successfully exonerating itself. ${ }^{28}$ In contrast to the claim made by the applicant in the case being discussed, the European Court of Justice came to the conclusion that the taxpayer commercial enterprise could decide to bring proof that though the burden of the tax was transferable, yet the inclusion of the tax in the price could have led to the decrease of revenues, which could be considered as an actual loss of the taxpayer. The taking into consideration of this circumstance rules out the possibility of finding financial gain without legal ground on the part of the taxpayer, which is relevant because this could otherwise be grounds for disallowing the execution of the compensation claim (Comateb, Para. 32).

The claim that the size of the damage is equal to the amount of tax that would not have had to have been paid had the national taxation rule not violated Community law is accepted in Community law practice, and this is backed up by the decisions of the European Court of Justice. An analogous example is the decision handed down in the Lindöpark case (C-150/99). Here the Court ruled for the applicant, and decided that the taxpayer applicant's legitimate claim for damages was equal to the transferred tax that could not be deducted in the period between the accession of the Kingdom of Sweden (January 1, 1995) and the amendment of the relevant legal rule some two years later (January 1, 1997). The reasoning was that this damage would not have occurred, if the tax would have been deductible, and had Swedish law been in harmony with Community law by allowing the deduction of the amount of transferred tax, as a result of officially recognizing the relevant taxable activity accordingly. The taxpayer's damages exactly equaled the amount of the nondeductible transferred tax, which the taxpayer could have deducted had the Kingdom of Sweden harmonized its law with the Sixth Council Directive following her accession. Naturally, the damage claim extends to the interest amount as well (Para. 13). The occurrence of the damage-in contrast to applicant's position-did not require further proof beyond the finding that the taxpayer could not take advantage of the possibility to deduct the amount of tax at issue.

In the joined cases of Metallgesellschaft (C-397/98) and Hoechst (C-410/98), the foreign parent companies petitioned for compensation of damages, because dividends paid by their British subsidiaries were subject to the payment of Advance Corporation Tax (ACT) according to British taxation rules, which was in their view a discriminatory measure as the liability to pay the ACT did not exist for holding companies of domestic resident status (Paragraphs 27 and

\footnotetext{
${ }^{28}$ Joined cases, C-192/95 and C-218/95 Société Comateb, European Court Reports
} 1997. I-165, Para. 25. 
29). The damage caused was determined to be equalling the amount of the ACT deducted from the dividends payments, i.e. the pecuniary disadvantage resulting from the payment of the ACT. The European Court of Justice found for the applicant, providing the reasoning, among others, that the national courts could not have reasonably required as a prerequisite of adjudicating the damage claim that the taxpayer first follow through with its potential legal conflict with the tax authority, in case it chooses to take advantage of the tax allowance available in the domestic context, and turn to the courts for legal redress only if the public administrative proceeding resulting from the legal conflict had ended inconclusively (Para. 107).

\section{Direct causation between the conduct of a Member State violating Community law and the damages that have occurred}

Since the damage occurred as a direct result of having had to pay the tax, which would have been avoidable had the Republic of Hungary repealed the relevant tax law rules following accession, the damages that have occurred could be proven by the applicant presenting as evidence those tax reports that show the existence of the tax payment liability being challenged, as well as the connected proofs of actual tax payments having been made. There is no necessity for presenting separate tax authoritative decisions in connection to proving the existence of the liability for the tax. It is a separate issue that the taxpayer did question the legality (validity of the legal grounds) of the liability to pay the tax at issue, and therefore the taxpayer had challenged the decision of the tax authority prescribing the payment of a tax advance before the courts, petitioning for the dismissal of the tax authority's decision, claiming that it was unlawful.

Naturally, the Hungarian State did not prescribe the applicant's obligation to pay the local business tax, but this obligation could not have materialized had the relevant national rule not been created. Consequently, the direct causeand-effect relation between the conduct of the person causing the damage and the damage caused is obviously present, especially if we take it into account that in absence of the relevant [national] legislation violating Community law, the local governments [in Hungary] would not have been able to rely on this form of taxation. We would like to note here that in the applicant's case all local governments involved did take advantage of the option to levy the local business tax without any exceptions. Consequently, the damages that have occurred were caused by the legislative act of the Hungarian State. The legal person of the local government could also be involved as co-defendant in the lawsuit (through its mayor's office), on the basis that naturally the municipality's 
decree mandating the payment of the local tax is itself in violation of Community law. This would however make no sense, because the capacity of local governments to issue decrees is based on legislative enablement, and the violation of Community law is an issue primarily connected to the erroneous piece of legislation. Action against the local government authority would also be appropriate, and in fact is expected of the taxpayer due to the obligation of the taxpayer to act to minimize the damage. The appropriate way to do this, however, is to petition for the review of the public administrative decision. This was in fact carried out by the applicant on every occasion. The basis for bringing suit against the Hungarian State is that taxpayer applicant's damages occurred as result of the act of enacting legislation that violates Community law. Consequently, applicant cannot limit the applicant's claim to just what would be damages caused while exercising public administrative power. While it is worth mentioning here that the applicant cannot rule out that the Hungarian State did not in fact cause damages while exercising state administrative power (and this is why we may cite Section $349 \mathrm{CC}$ ), nevertheless, the proper legal basis for the applicant's claim is Section 339 CC.

\section{Concluding remarks}

Even though, following the ECJ decision in C-283/06 Kögáz and C-312/06 OTP Garancia Biztosító, it can be concluded that the Hungarian local trade tax cannot be considered inconsistent with Community law, the taxpayer's rights are infringed, being compelled, as a result of the tax authority's failure to interpret the Hungarian law on local trade tax in the light of the respective Community law, to enter into a burdensome procedure. In fact, for the lack of interpreting the Hungarian law on local trade tax in terms of dealing with an appeal the taxpayer made against the tax authority's first-instance decision on the imposition of advance local trade tax, the taxpayer has to file a tax return with zero tax liability and assuming the risk that this return would most likely be challenged by the competent tax authority.

Notably, the problem of Hungarian law has not to date recovered in the instance that the taxpayer is not granted to file tax returns with the reservation of his or her right to challenge the legal basis of the imposition of tax. Where under Hungarian law it is possible that the tax authorities avoid interpreting the compatibility of the Hungarian law on local trade tax in the light of Community law in terms of an appeal the taxpayer may make against the tax authority's first-instance decision on the imposition of advance local trade tax, the question can be raised if the Republic of Hungary has infringed the loyalty 
requirement of Article $10 \mathrm{EC}$ by preventing taxpayers from the efficient enforcement of their rights. It is an open issue, however, if a claim against the national legislation of a Member State can be based solely on the infringement of Article $10 \mathrm{EC}$ or, in addition to it, the claimant could be requested to show the infringement of some substantive provisions of national law in association with the alleged infringement of Article 10 EC. 